
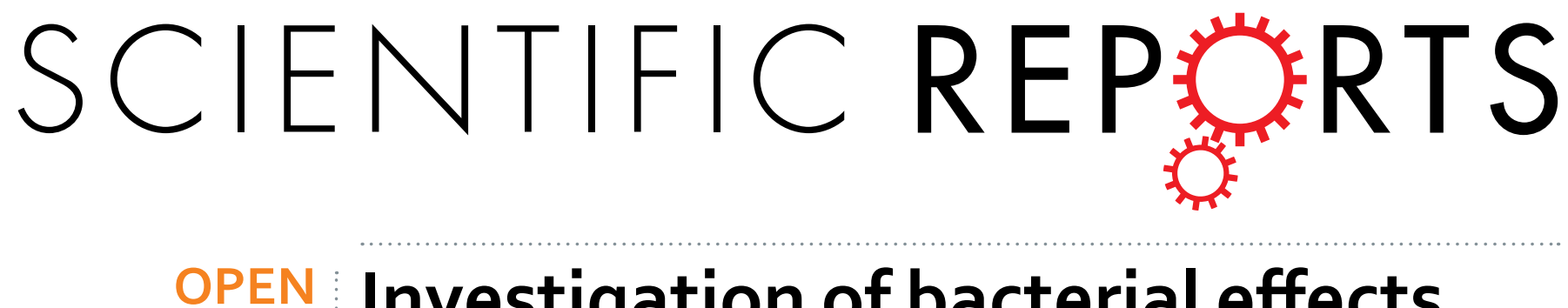

\title{
Investigation of bacterial effects of Asian dust events through comparison with seasonal \\ variability in outdoor airborne bacterial community
}

Received: 13 May 2016

Accepted: 16 September 2016

Published: 20 October 2016

\author{
Jonguk Park ${ }^{1}$, Tomoaki Ichijo ${ }^{1}$, Masao Nasu ${ }^{1,2} \&$ Nobuyasu Yamaguchi, ${ }^{1,3}$
}

Atmospheric bacterial dispersion with aeolian dust has been reported to have a potential impact on public health and ecosystems. Asian dust is a major aeolian event that results in an estimated 4 million tons of Asian dust particles falling in Japan annually, 3,000-5,000 km away from their source regions. However, most studies have only investigated the effects of Asian dust during dust seasons. Therefore, in this study, outdoor bacterial abundance and community composition were determined by 16S rRNA quantitative PCR and amplicon sequencing, respectively, and compared on Asian and non-Asian dust days (2013-2015; 44 samples over four seasons). Seasonal variations in bacterial abundance of nonAsian dust days were not observed. Bacterial abundance of individual samples collected on non-Asian dust days changed dynamically relative to Asian dust days, with bacterial abundance occasionally reaching those of Asian dust days. The bacterial community composition on non-Asian dust days was rather stable seasonally, and did not differ from that on Asian dust days. These results indicate that bacteria in Asian dust does not immediately influence indigenous bacterial communities at the phylum/class level in distant downwind areas; accordingly, further studies of bacterial communities in downwind areas closer to the dust source are warranted.

Aeolian dust is a natural phenomenon that primarily occurs in arid and semi-arid regions such as deserts and areas with loess. In this phenomenon, sand particles are lifted by ascending air currents and transported over long distances (hundreds or thousands of kilometers). Approximately $0.5-5.0$ billion tons of aeolian dust are transported each year worldwide ${ }^{1}$. Major aeolian dust events arise from the Sahara and Sahel deserts (African dust), the Australian deserts (Australian dust), and the Taklamakan and Gobi deserts and the Loess Plateau (Asian dust).

Atmospheric currents and ocean currents are the main vehicles of bacterial migration, and it has been reported that bacteria adhered to aeolian dust particles may impact public health and ecosystems ${ }^{2-5}$. It is estimated that approximately four million tons of Asian dust particles fall on Japan each year ${ }^{6}$, which is $3,000-5,000 \mathrm{~km}$ away from their source regions. In addition, Asian dust particles sometimes reach North America, more than $15,000 \mathrm{~km}$ from their source regions ${ }^{7,8}$. Several investigations of airborne bacteria have been conducted to evaluate potential health effects of long-distance transport of bacteria by Asian dust, including analyses of bacterial community composition ${ }^{9}$, abundance and viability ${ }^{10}$, as well as investigations of atmospheric halotolerant bacterial communities ${ }^{11}$.

Previous studies of aeolian dust using culture-dependent methods have reported the airborne transport of pathogens and their resultant health effects ${ }^{4,8}$. However, community analyses using culture-independent methods have confirmed that aeolian dust transported not only pathogenetic bacteria, but also phylogenetically diverse bacteria ${ }^{9,11-14}$. In addition, most studies have been conducted only during Asian dust events (March to June) ${ }^{9-12,14}$,

${ }^{1}$ Graduate School of Pharmaceutical Sciences, Osaka University, 1-6 Yamada-oka, Suita, Osaka 565-0871, Japan. ${ }^{2}$ Faculty of Pharmacy, Osaka Ohtani University, 3-11-1 Nishikiori-kita, Tondabayashi, Osaka 584-8540, Japan. ${ }^{3}$ Osaka Prefectural Institute of Public Health, 1-3-69 Nakamichi, Higashinari, Osaka 537-0025, Japan. Correspondence and requests for materials should be addressed to N.Y. (email: nyyamaguchi@iph.pref.osaka.jp) 


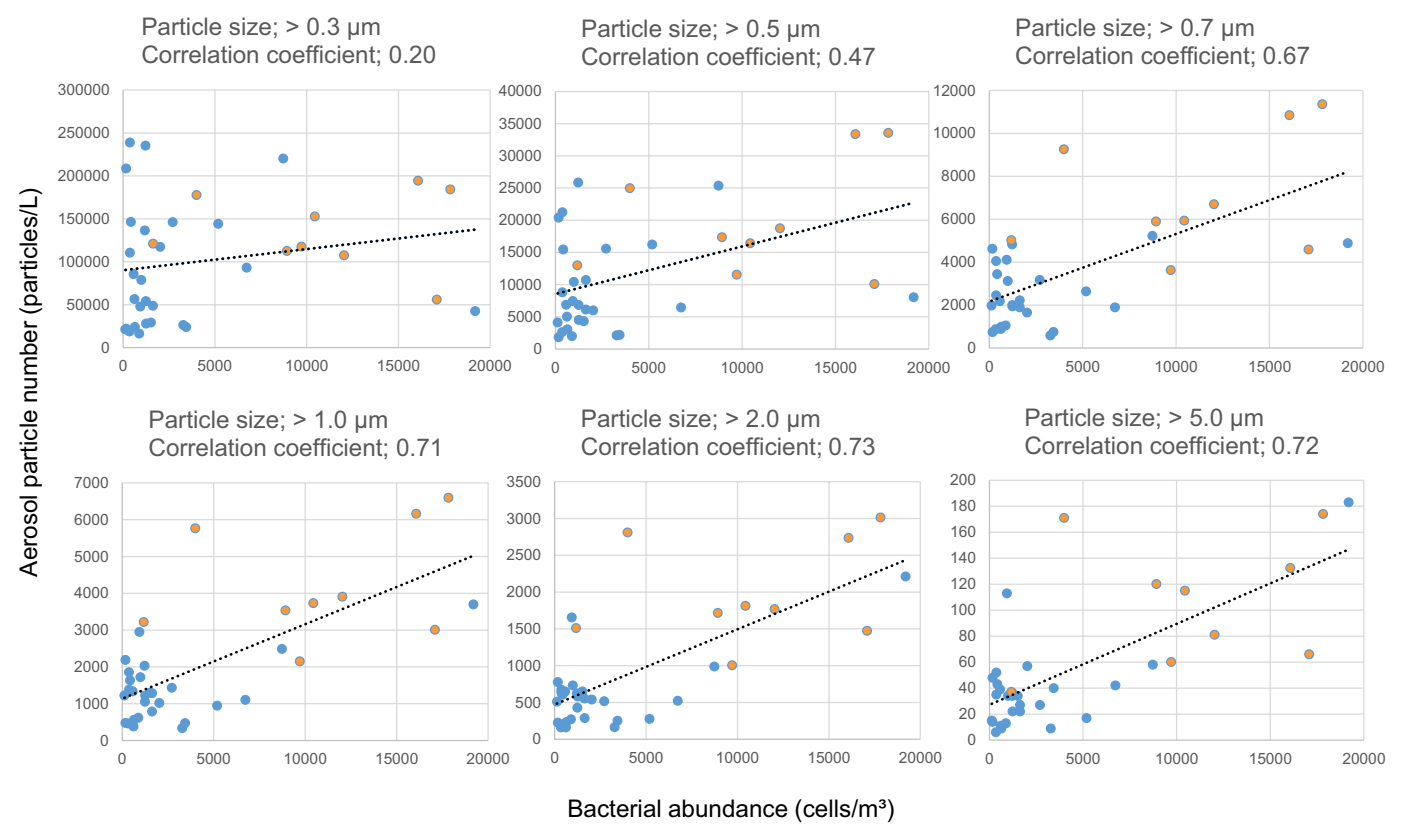

Figure 1. Correlation of bacterial abundance with particle size distribution. The bacterial abundance was determined by quantitative PCR targeting the 16S rRNA gene (V6-V8). Blue and yellow indicate non-Asian and Asian dust samples, respectively.

even though the bacterial abundance and community composition of aerosols in outdoor environments are thought to be affected by seasonal and weather-related variations ${ }^{15-19}$. To assess the effects of bacteria transported with aeolian dust on public health and the environment, bacterial variations should be evaluated by long-term monitoring.

Therefore, the present study was conducted to investigate the effects of bacteria transported by Asian dust events on humans and the ecosystem based on outdoor aerosol samples collected on both Asian dust and non-Asian dust days from 2013 to 2015 . We analyzed variations in bacterial abundance and bacterial community composition on non-Asian dust days to understand variations in the local airborne bacterial community. We then investigated airborne bacterial community characteristics following Asian dust events through comparison with seasonal bacterial community variability on non-Asian dust days and changes in the bacterial community on Asian dust days. Airborne bacterial abundance and community composition were determined by $16 \mathrm{~S}$ rRNA gene-targeted quantitative PCR and amplicon sequencing, respectively.

\section{Results}

Variations in bacterial abundance on non-Asian dust days and comparison with bacterial abundance on Asian dust days. Particle size distribution of aerosols in the outdoor environments was measured (Supplementary Fig. S1). The number of particles in the outdoor environment was changed by 10 fold. During Asian dust events, particle number was generally elevated, and comparatively large particles were dynamically elevated (P value; $>0.3 \mu \mathrm{m}[0.0255],>0.5 \mu \mathrm{m}$ [0.0069], $>0.7 \mu \mathrm{m}[0.0011],>1.0 \mu \mathrm{m}[0.0003],>2.0 \mu \mathrm{m}[0.0002]$, $>5.0 \mu \mathrm{m}[0.0028])$. The results revealed a correlation between bacterial abundance and particle size distribution, with particle sizes larger than $1.0 \mu \mathrm{m}$ showing a greater correlation (Fig. 1).

Accordingly, we compared bacterial abundance and number of particles larger than $1.0 \mu \mathrm{m}$ during different seasons, rainfall events, and Asian dust occurrences (Fig. 2). The levels of particles larger than $1.0 \mu \mathrm{m}$ fluctuated between $3 \times 10^{2}$ and $3 \times 10^{3} \mathrm{~L}^{-1}$, regardless of season. On Asian dust days, particle levels ranged from $2 \times 10^{3}$ to $7 \times 10^{3} \mathrm{~L}^{-1}$. Particle numbers on Asian dust days were higher than those on non-Asian dust days, and their fluctuation was more stable on Asian dust days.

Bacterial abundance in outdoor environments varied with variations in particle number (Fig. 2; $1 \times 10^{2}-1 \times 10^{4}$ cells $\mathrm{m}^{-3}$ ), and bacterial abundance was not influenced by rainfall in this study. However, bacterial abundance generally increased as the number of particles $(>1.0 \mu \mathrm{m})$ increased, without response to seasonal variations or occurrence of Asian dust (correlation coefficient; $r>0.7$ ). Bacterial abundance on Asian dust days was generally greater than $10^{4}$ cells $\mathrm{m}^{-3}$. The average bacterial abundance on Asian dust days $\left([1 \pm 0.6] \times 10^{4} \mathrm{cells}^{-3}\right)$ increased by approximately 5 times relative to non-Asian dust days $\left([2 \pm 3] \times 10^{3}\right.$ cells $\left.\mathrm{m}^{-3}\right)$. However, bacterial abundance fluctuated from $10^{2}$ to $10^{4}$ cells $\mathrm{m}^{-3}$ on non-Asian dust days and changed dynamically relative to Asian dust days, with bacterial abundance reaching that of Asian dust days on several occasions (20 August, 27 August, 3 September, and 14 September, 2013; 16 April and 23 April, 2015).

The ratio of bacterial abundance to number of particles $(>1.0 \mu \mathrm{m})$ was comparatively higher in summer and fall $(0.56 \%$ and $0.28 \%$, respectively). However, this ratio was lower in winter than in other seasons $(0.15 \%$ in 


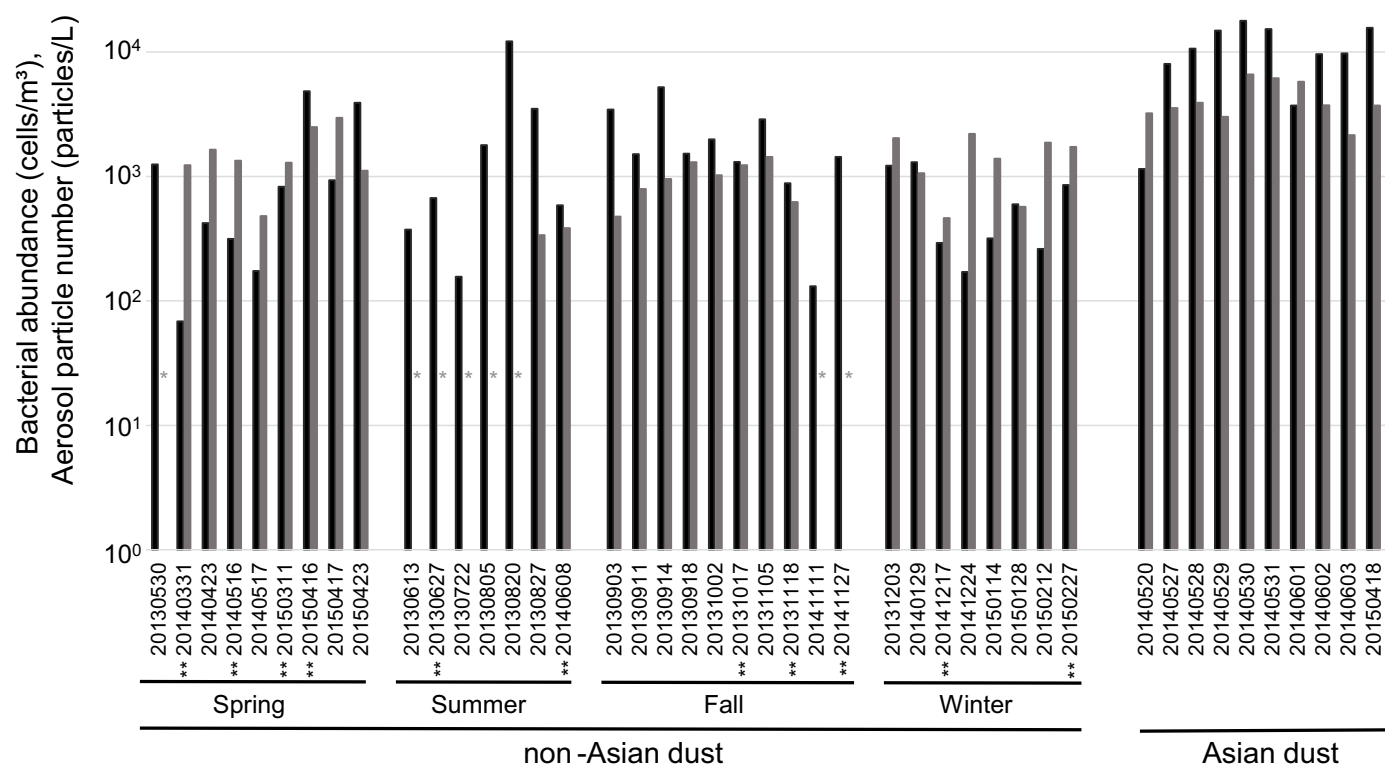

Figure 2. Total bacterial abundance (black bar) determined by quantitative PCR targeting the 16S rRNA gene and total aerosol particle numbers (particle size: $>1.0 \mu \mathrm{m}$ [gray bar]) determined by particle counter. Samples were collected during each of the four seasons, including after rainy days and Asian dust days.

spring, $0.06 \%$ in winter). On Asian dust days, the ratio of bacterial abundance to particle number was $0.30 \%$ and stable relative to non-Asian dust days.

Variations in bacterial community composition on non-Asian dust days and comparison with bacterial community composition on Asian dust days. To investigate the bacterial effects of Asian dust, we also analyzed bacterial community composition with variations in environmental conditions on non-Asian dust days. Airborne bacterial community composition in outdoor environments has been reported to change in response to variations in environment factors ${ }^{15-19}$. In this study, the airborne bacterial community composition was determined using $16 \mathrm{~S}$ rRNA gene targeted ion PGM sequencing in conjunction with a two-step PCR method. Two-step PCR has advantages such as increased reproducibility and recovery of higher genetic diversity during amplicon sequencing ${ }^{20,21}$.

In the two-step PCR method, we used the 968f-1401r primer (V6-V8) set because it produced the highest diversity in a preliminary study using PCR-DGGE to select the proper primer (Supplementary Fig. S2). To analyze similarities in the bacterial community composition of each sample, amplicon sequencing data of bioaerosol samples were processed using the QIIME software, and the results were indicated using multidimensional scaling (MDS) (Fig. 3). The results revealed that bacterial community composition in the outdoor environment was rather stable, despite changes in season, and samples were generally not affected by variations in environmental factors. However, the bacterial community compositions of samples collected on 5 August 2013 and 11 November 2014 differed from others. In addition, bacterial community composition did not differ significantly on Asian dust days and non-Asian dust days. Comparative analysis of the bacterial community composition at the phylum and class level revealed that environmental factors such as season and rainfall had no effect on the predominant bacterial phylum and class (Fig. 4).

The predominant phyla and classes on non-Asian dust days were Acidobacteria (25 $\pm 19 \%)$, Actinobacteria (17 $\pm 9 \%)$, Bacilli (15 $\pm 16 \%)$, Cyanobacteria ( $8 \pm 7 \%)$, Alphaproteobacteria $(5 \pm 4 \%)$, Gammaproteobacteria $(5 \pm 9 \%)$, Betaproteobacteria $(4 \pm 2 \%)$, Clostridia $(3 \pm 2 \%)$, and Deinococci $(2 \pm 3 \%)$ (Fig. 5$)$. No specific phylum or class accounted for more than half of the total bacterial community. Variations in the bacterial community composition between seasons did not exceed more than double the original concentration. On Asian dust days, the bacterial community composition was similar to that on non-Asian dust days, with dominant mem-

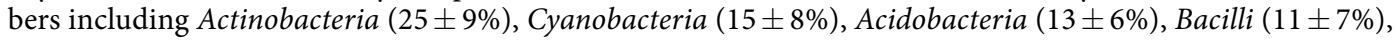
Gammaproteobacteria $(7 \pm 4 \%)$, Betaproteobacteria $(6 \pm 2 \%)$, Alphaproteobacteria $(4 \pm 2 \%)$, Deinococci $(3 \pm 2 \%)$, and Clostridia $(2 \pm 1 \%)$ (Fig. 5). Changes in the outdoor airborne bacterial community composition in response to Asian dust did not exceed those observed on non-Asian dust days.

On 5 August, 2013, the bacterial community composition differed from that observed on other sampling dates, with Acidobacteria being the dominant member (78\%). Acidobacteria are generally the dominant phyla in soil habitats ${ }^{22}$. Additionally, on 11 November, 2014, Gammaproteobacteria, which is known to exist in diverse environments, was dominant (50\%). Bacilli can form spores and withstand severe conditions such as those found in sources of Asian dust ${ }^{23}$. There have been many reports of increased levels of Bacilli on Asian dust days in 

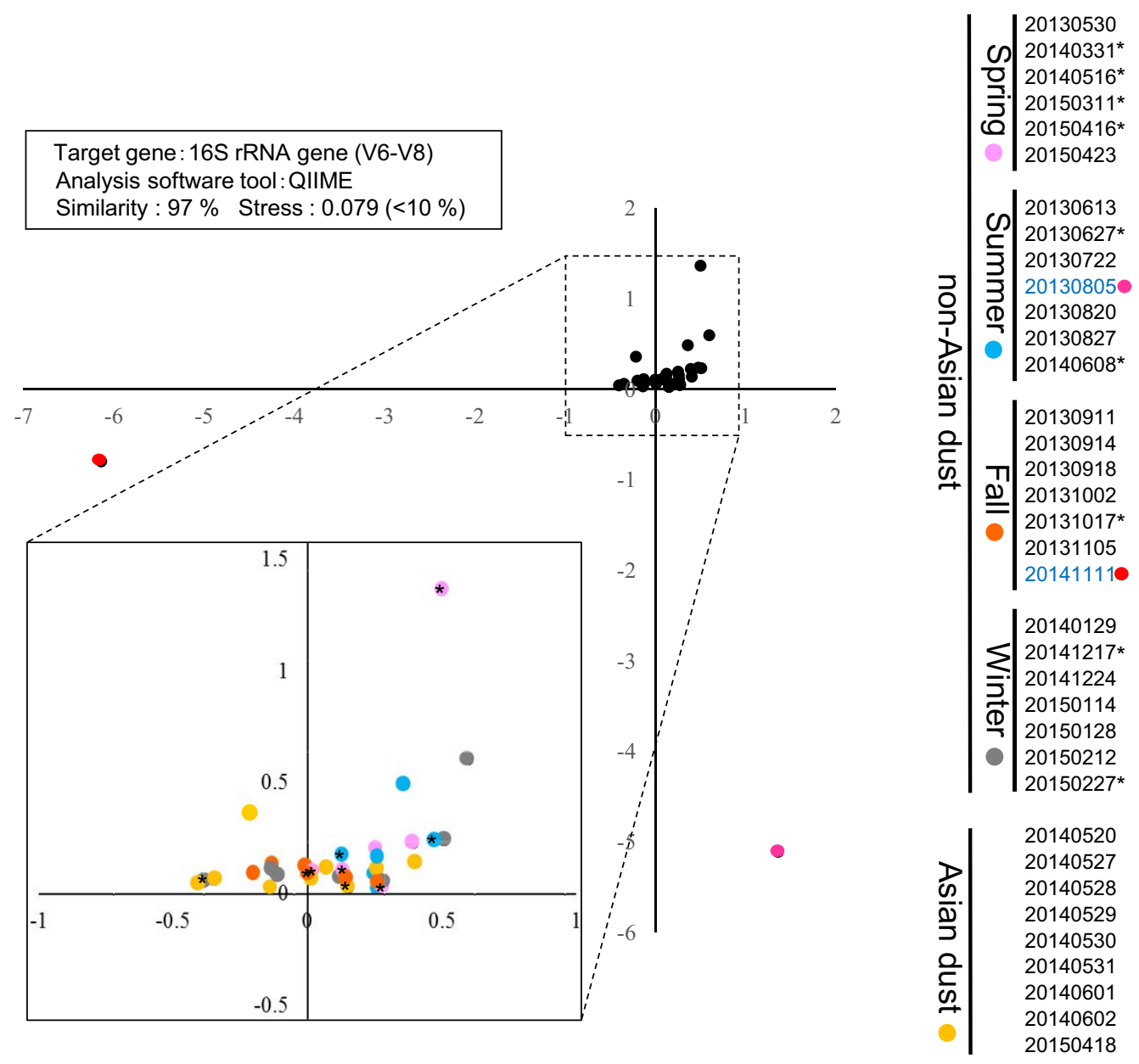

*After rainy day

Figure 3. Multidimensional scaling (MDS) analysis of bacterial 16S rRNA genes obtained from aerosols in outdoor environments.

downwind regions far from the source regions of Asian dust ${ }^{9}$; however, Bacilli accounted for more than $50 \%$ of the population on several non-Asian dust days in this study (13 June, 2013 [54\%], 12 Febraury, 2015 [78\%]). Bacilli did not increase in response to Asian dust events in this downwind area.

\section{Discussion}

In this study, bacterial number and community composition were calibrated based on copy number of 16S rRNA gene of each bacterial phylum. This was conducted because both high copy number bacteria (e.g., Bacilli) and low copy number bacteria (e.g., Acidobacteria) were present in the collected dust samples.

Although bacterial abundance has been reported to change in response to variations in environmental factors $^{15-19}$, it was not correlated with any environmental factors (season, temperature, humidity, wind speed, wind direction, rainfall) except particle numbers in the present study. During winter, the ratio of bacterial abundance to particle number was low relative to other seasons. Atmospheric bacterial abundance would be lower in winter because of the response to low temperature ${ }^{24}$.

No considerable increase in bacterial abundance was observed on Asian dust days relative to fluctuations in bacterial abundance on non-Asian dust days. Bacterial abundance on aerosols of indoor environments usually ranges from $10^{5}$ to $10^{6}$ cells $\mathrm{m}^{-325}$, and bacterial abundance in outdoor environments determined in this study was 10-100 times lower than those in indoor environments.

The results on non-Asian dust days appeared to be correlated with the environmental characteristics of the sampling location. Specifically, we monitored bioaerosols in environments in which temperatures are suitable to the growth of general bacteria (from $4^{\circ} \mathrm{C}$ to $34^{\circ} \mathrm{C}$; average $21 \pm 9^{\circ} \mathrm{C}$ ). It has been reported that bacterial abundance and community composition changed significantly in response to season in specific places (e.g., coastal sites ${ }^{15}$, high-elevation sites ${ }^{16}$ ). However, none of our sampling points were located in places such as these. Variations in atmospheric bacterial community composition in outdoor environments impacted by Asian dust occurrence were more stable than those observed on non-Asian dust days. Accordingly, these findings indicate that bacterial effects on humans and ecosystems in distant downwind areas impacted by Asian dust may be lower than those of general changes in the natural environment. 


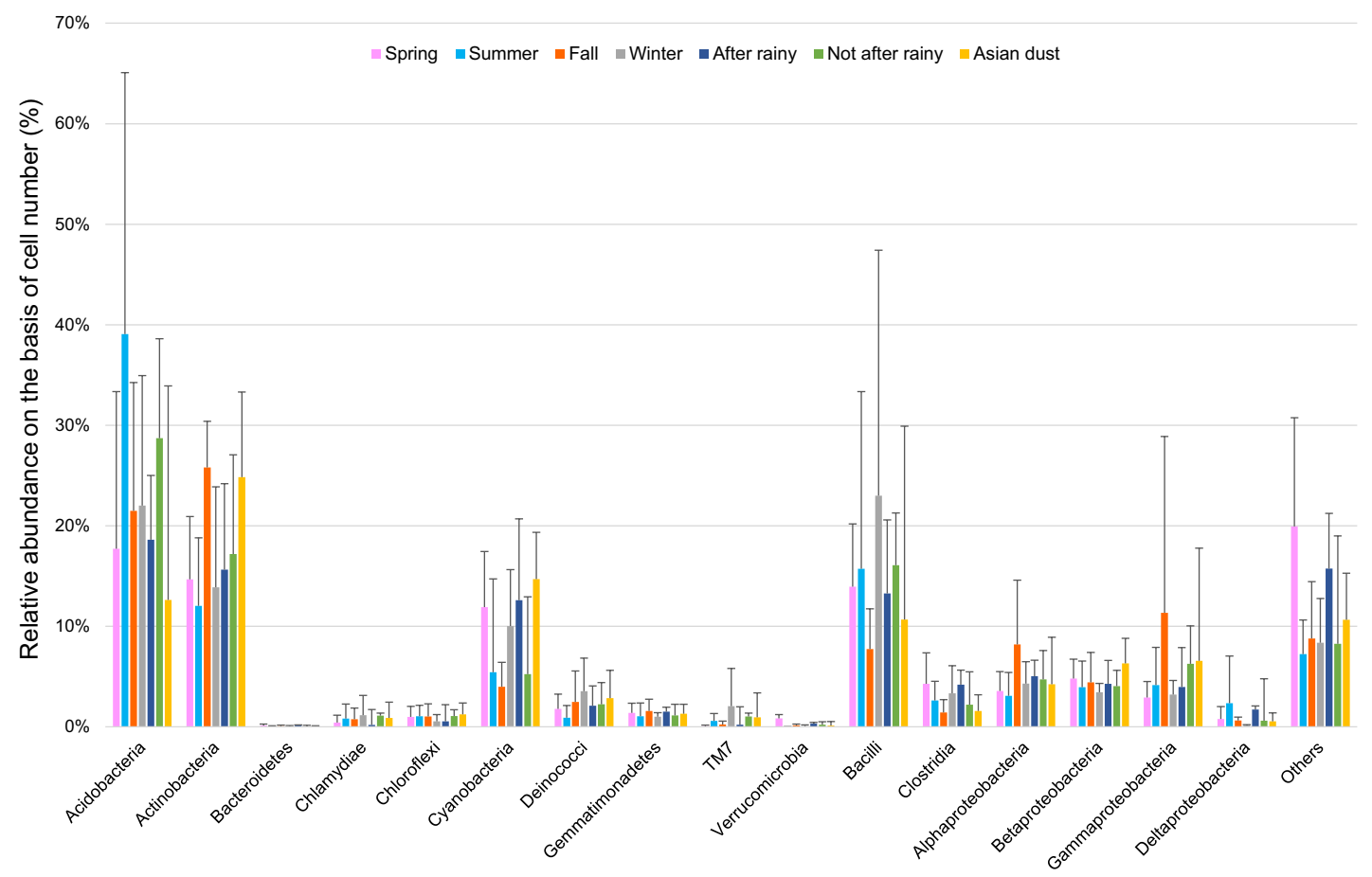

Figure 4. Relative abundance of each common phyla and class in outdoor samples (classified by season, weather conditions, and Asian dust events).

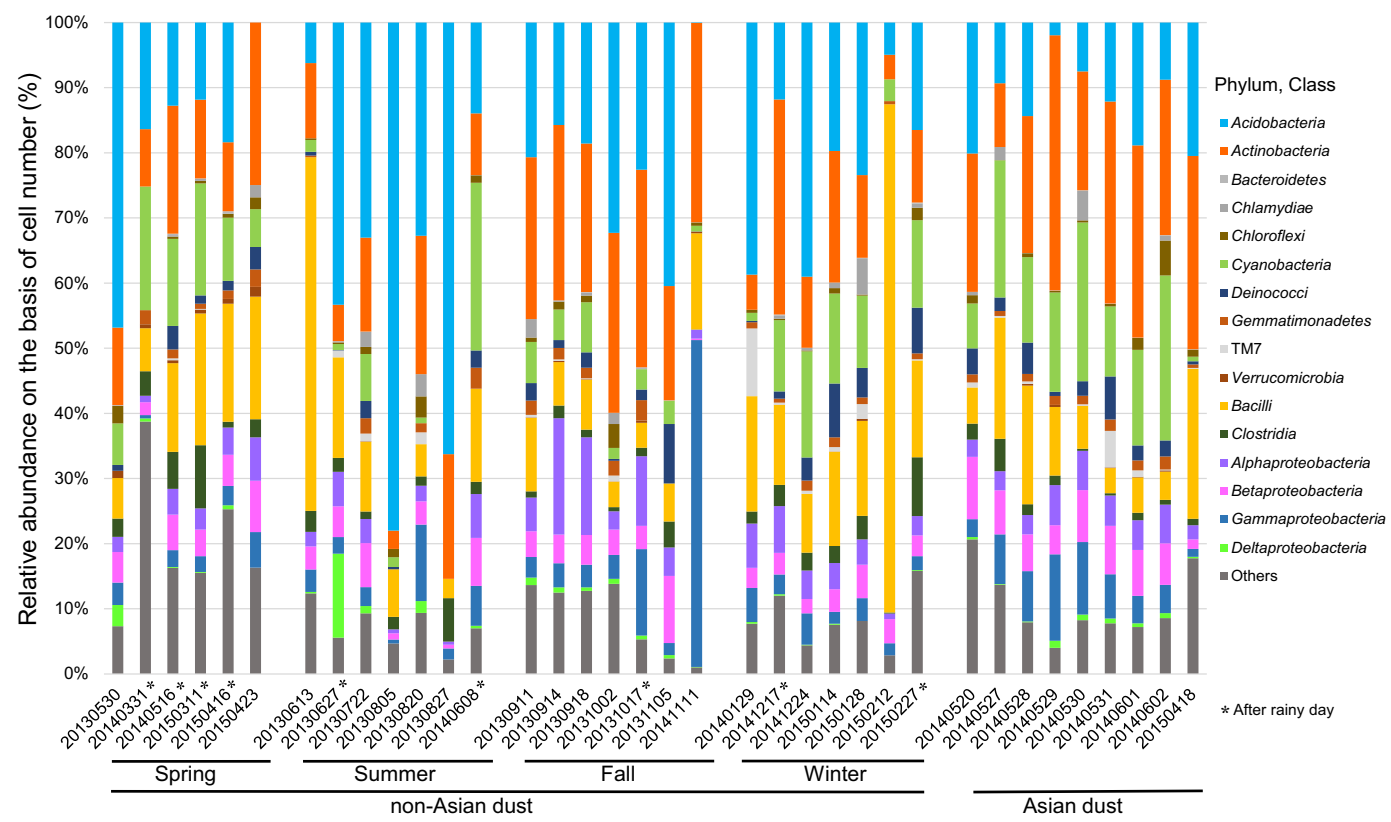

Figure 5. Taxonomic composition of each sample of outdoor airborne bacterial communities. Composition estimates are based on relative abundances of bacterial 16S rRNA gene sequences assigned to different common phyla and classes.

Information describing the viability of airborne bacteria collected on Asian dust days can help accurately estimate their influences on public health and ecosystems. Several methods, such as fluorescent vital stain ${ }^{10}$, can be used to estimate bacterial activity in aquatic and soil environments. However, bacterial abundance in atmospheric environments is much lower than in other natural environments; therefore, accurate evaluation of viability of airborne bacteria remains difficult. In addition, new methods are required to simultaneously obtain bacterial viability and phylogenetic information. 
We demonstrated that bacteria in Asian dust that had been transported long distances did not immediately influence the bacterial community in downwind areas. Furthermore, our findings suggest that bacterial communities may be affected more by ground environments along the transfer route and local environments than by the bacterial community in the dust itself. However, more severe occurrences of Asian dust in areas closer to the dust source may result in microbes in the dust having a greater impact on the indigenous bacterial community. The amount of Asian dust fallout is estimated to be $180 \mathrm{~g} \mathrm{~m}^{-2}$ year $^{-1}$ in Beijing, China ${ }^{26}(500-2,500 \mathrm{~km}$ from the dust source region) and $0.005-0.05 \mathrm{~g} \mathrm{~m}^{-2}$ year $^{-1}$ in Osaka, Japan ${ }^{6}(3,000-5,000 \mathrm{~km}$ from the dust source region). Accordingly, future studies of the bacterial community in downwind areas closer to the source are warranted to better assess the impacts of aeolian dust on public health and ecosystems.

\section{Materials and Methods}

Sample collection. Aerosol samples were collected from the rooftop of a building (ca. $20 \mathrm{~m}$ in height) at

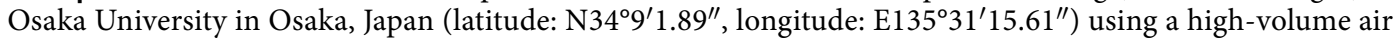
sampler (HV500R [SIBATA, Saitama, Japan]). The sampling point was located approximately $12 \mathrm{~km}$ from a major downtown area, and there were no industrial plants, agricultural fields or superhighways around the sampling point. Air samples were collected on $0.6 \mu \mathrm{m}$ pore-size glass fiber filters at $500 \mathrm{~L} \mathrm{~min}^{-1}$. Aerosol particles from a total of $100 \mathrm{~m}^{3}$ of ambient air were collected during each sampling event (sampling time: $200 \mathrm{~min}$ ). Furthermore, particle size distribution $(>0.3 \mu \mathrm{m},>0.5 \mu \mathrm{m},>0.7 \mu \mathrm{m},>1.0 \mu \mathrm{m},>2.0 \mu \mathrm{m}$, and $>5.0 \mu \mathrm{m})$ was determined using a particle counter (ARTI HHPC-6 [HACH, Tokyo, Japan]). Overall, 44 samples were obtained on different days between May 2013 and April 2015, including Asian dust days (20 May 2014, 27-31 May 2014, 1-3 June 2014, and 18 April 2015), all four seasons and after rainy days (Table 1). The occurrence of atmospheric Asian dust was confirmed using information from the Japan Meteorological Agency, LIDAR (Light Detection and Ranging) data from the Ministry of the Environment, Japan (http://www-gis5.nies.go.jp/eastasia/DustLider.php), and visibility at the sampling location (Supplementary Fig. S3).

The geographic origins of Asian dust collected in this study were determined by back trajectory analysis (http://ready.arl.noaa.gov/HYSPLIT.php), and we confirmed that the origin of all Asian dust samples was the Gobi Desert.

DNA extraction. Aerosol samples collected on the glass filter were pulverized by bead-beating (EZ-Beads [EZ, Tokyo, Japan], 4,800 rpm, about $90 \mathrm{~s}$ ). DNA was then extracted and purified using the method described by Tsai and Olson ${ }^{27}$. Extracted DNA was subsequently purified using a Wizard DNA Clean-Up System kit (Promega, Madison, WI, USA) and eluted with $50 \mu \mathrm{L}$ of TE buffer $(10 \mathrm{mM}$ Tris- $\mathrm{HCl}$ and $1 \mathrm{mM}$ EDTA [pH 8.0]).

Estimation of bacterial abundance. To determine bacterial abundance, 16S rRNA gene was quantified by real-time PCR using a LightCycler (Roche Diagnostics, Mannheim, Germany). Real-time PCR was performed with eubacterial primer sets as described by Yamaguchi et al. ${ }^{12}$. A total of $1 \times 10^{1}$ to $1 \times 10^{7}$ copies per reaction of PCR products of E. coli W3110 were used as the DNA template to generate a standard curve for quantification of the $16 \mathrm{~S}$ rRNA gene. The copy number of the $16 \mathrm{~S}$ rRNA gene differed among bacterial phyla; therefore, bacterial abundance was calibrated based on the results of bacterial community composition analysis at the phylum level.

Analysis of bacterial community composition. Two-step PCR was conducted to amplify the 16S rRNA gene for pyrosequencing ${ }^{28}$. Using this approach, tags and adapters were added in a second round of PCR amplification. The first PCR amplification was conducted using the universal primers 968F (AACGCGAAGAACCTTAC) and 1401R (CGGTGTGTACAAGACCC) to amplify a 434-bp fragment of the 16S rRNA gene between the V6 and V8 regions ${ }^{29}$. PCR amplification was performed using the reagents supplied with the AmpliTaq Gold kit (Applied Biosystems, Carlsbad, CA, USA). The reaction mixture contained $2.5 \mathrm{U} \mathrm{mL}^{-1}$ AmpliTaq Gold, $0.5 \mu$ of each primer, $0.2 \mathrm{mM}$ of each dNTP, $1.5 \mathrm{mM} \mathrm{MgCl}_{2}$, and $12.5 \mu \mathrm{g} \mathrm{mL}^{-1}$ 8-methoxypsoralen (Sigma Aldrich, St. Louis, MO, USA; dissolved in dimethyl sulfoxide) in $49 \mu \mathrm{L}$ PCR buffer. A $1-\mu \mathrm{L}$ DNA suspension was added after irradiation of the PCR mixture with ultraviolet light ${ }^{30}$. The reaction cycle consisted of an initial denaturing step at $94^{\circ} \mathrm{C}$ for $9 \mathrm{~min}$, followed by 10 cycles of denaturing at $95^{\circ} \mathrm{C}$ for $1 \mathrm{~min}$, annealing at $63-53^{\circ} \mathrm{C}\left(\right.$ decreased by $1{ }^{\circ} \mathrm{C}$ per cycle) for $1 \mathrm{~min}$, and extension at $72^{\circ} \mathrm{C}$ for $3 \mathrm{~min}$. This was followed by 20 cycles of denaturing at $95^{\circ} \mathrm{C}$ for $1 \mathrm{~min}$, annealing at $53^{\circ} \mathrm{C}$ for $1 \mathrm{~min}$, and extension at $72^{\circ} \mathrm{C}$ for $3 \mathrm{~min}$, with a final extension step at $72^{\circ} \mathrm{C}$ for $10 \mathrm{~min}$. Primary PCR products were then purified using a MonoFas PCR Purification Kit (GL Sciences, Tokyo, Japan) and eluted with $40 \mu \mathrm{L}$ of TE buffer. Next, a second round of PCR was performed as described above, except primers with an adapter and barcodes of 10 nucleotides in length were used. Furthermore, the number of PCR cycles was reduced to 20 ( 10 cycles of annealing at $63-53^{\circ} \mathrm{C}$ and 10 cycles of annealing at $\left.53^{\circ} \mathrm{C}\right)$. Amplicon sequencing using Ion PGM (Thermo Fisher Scientific KK, Yokohama, Japan) was carried out at the Center for Medical Research and Education, Osaka University (Osaka, Japan).

Raw sequence data of the obtained amplicons were screened, trimmed, and filtered using the default settings of QIIME pipeline version 1.9.1 (http://qiime.org/), resulting in over 125,000 sequences across all samples $(3,200$ sequences per sample, on average). Total operational taxonomic units (OTUs), which were defined at the $97 \%$ nucleotide-sequence identity level using the UCLUST function of the QIIME software ${ }^{31}$, were identified in all sequences, with about 1,500 OTUs per sample on average being recovered. Beta diversity measures were also calculated. Differences in community composition of each sample were assessed graphically using the ordination method of non-metric MDS calculated based on the Euclidean distance. 


\begin{tabular}{|c|c|c|c|c|c|c|c|c|c|c|}
\hline ID & $\begin{array}{c}\text { Sampling } \\
\text { date }\end{array}$ & Season & Start & End & $\begin{array}{l}\text { Asian } \\
\text { dust }^{*}\end{array}$ & Weather & $\begin{array}{l}\text { Temp. } \\
\left({ }^{\circ} \mathrm{C}\right)\end{array}$ & $\begin{array}{c}\text { Relative } \\
\text { humidity (\%) }\end{array}$ & $\begin{array}{c}\text { Wind speed } \\
\left(\mathrm{m} \mathrm{s}^{-1}\right)\end{array}$ & $\begin{array}{c}\text { Wind } \\
\text { Direction }\end{array}$ \\
\hline 1 & 20130530 & Spring & $10: 00$ & $13: 20$ & - & & 24.9 & N. D. & 3 & SW \\
\hline 2 & 20130613 & Summer & $10: 30$ & $13: 50$ & - & & 18.4 & N. D. & 3 & SW \\
\hline 3 & 20130627 & Summer & $9: 10$ & $12: 30$ & - & After rainy & 26.9 & N. D. & 3 & NW \\
\hline 4 & 20130722 & Summer & $10: 00$ & $13: 20$ & - & & 31.5 & N. D. & 4 & SW \\
\hline 5 & 20130805 & Summer & 10:00 & $13: 20$ & - & & 33.4 & N. D. & 3 & SW \\
\hline 6 & 20130820 & Summer & 10:00 & 13:20 & - & & 34.7 & N. D. & 3 & SSW \\
\hline 7 & 20130827 & Summer & $10: 00$ & $13: 20$ & - & & 30.2 & 46 & 3 & NW \\
\hline 8 & 20130903 & Fall & 10:00 & $13: 20$ & - & & 27.5 & 72 & 3 & ENE \\
\hline 9 & 20130911 & Fall & $10: 00$ & $13: 20$ & - & & 30.1 & 52 & 2 & SSW \\
\hline 10 & 20130914 & Fall & $10: 20$ & $13: 40$ & - & & 30.9 & 59 & 6 & $\mathrm{E}$ \\
\hline 11 & 20130918 & Fall & 10:00 & $13: 20$ & - & & 27.5 & 50 & 2 & $\mathrm{NE}$ \\
\hline 12 & 20131002 & Fall & 10:00 & $13: 20$ & - & & 25.4 & 56 & 2 & NW \\
\hline 13 & 20131017 & Fall & 10:00 & $13: 20$ & - & After rainy & 19.2 & 39 & 6 & $\mathrm{~N}$ \\
\hline 14 & 20131105 & Fall & $10: 40$ & $14: 00$ & - & & 18.1 & 36 & 3 & $\mathrm{~N}$ \\
\hline 15 & 20131118 & Fall & $10: 10$ & 13:30 & - & After rainy & 12.7 & 31 & 5 & WSW \\
\hline 16 & 20131203 & Winter & 10:00 & $13: 20$ & - & & 11.9 & 42 & 3 & SW \\
\hline 17 & 20140129 & Winter & $15: 30$ & 19:00 & - & & 9.7 & 24 & 1 & SE \\
\hline 18 & 20140331 & Spring & $9: 40$ & 13:00 & - & After rainy & 15.6 & 23 & 5 & $\mathrm{~N}$ \\
\hline 19 & 20140423 & Spring & $8: 40$ & $12: 00$ & - & & 19.4 & 31 & 3 & SW \\
\hline 20 & 20140516 & Spring & $11: 50$ & $15: 10$ & - & After rainy & 22.6 & 36 & 4 & SSW \\
\hline 21 & 20140517 & Spring & 12:00 & $15: 20$ & - & & 22.2 & 26 & 3 & NW \\
\hline 22 & 20140608 & Summer & $10: 40$ & $14: 00$ & - & After rainy & 27.3 & 54 & 3 & SSW \\
\hline 23 & 20141111 & Fall & 10:00 & $13: 20$ & - & & 17.4 & N. D. & 1 & ESE \\
\hline 24 & 20141127 & Fall & 11:00 & $14: 20$ & - & After rainy & 17.0 & N. D. & 5 & $\mathrm{~N}$ \\
\hline 25 & 20141217 & Winter & 10:00 & 13:20 & - & After rainy & 3.5 & 29 & 6 & $\mathrm{~W}$ \\
\hline 26 & 20141224 & Winter & 10:00 & $13: 20$ & - & & 8.7 & 47 & 2 & SW \\
\hline 27 & 20150114 & Winter & 10:00 & $13: 20$ & - & & 6.5 & 44 & 2 & ENE \\
\hline 28 & 20150128 & Winter & $10: 10$ & 13:30 & - & & 5.6 & 29 & 6 & NNW \\
\hline 29 & 20150212 & Winter & 10:00 & $13: 20$ & - & & 7.0 & 47 & 3 & WSW \\
\hline 30 & 20150227 & Winter & 10:00 & $13: 20$ & - & After rainy & 8.2 & 29 & 5 & $\mathrm{~N}$ \\
\hline 31 & 20150311 & Spring & 10:00 & $13: 20$ & - & After rainy & 5.8 & 30 & 5 & WSW \\
\hline 32 & 20150416 & Spring & 11:00 & $14: 20$ & - & After rainy & 18.9 & 42 & 4 & SW \\
\hline 33 & 20150417 & Spring & 10:10 & 13:30 & - & & 17.2 & 31 & 2 & $\mathrm{~N}$ \\
\hline 34 & 20150423 & Spring & 11:10 & $14: 30$ & - & & 20.7 & 27 & 3 & $S$ \\
\hline 35 & 20140520 & Spring & $10: 00$ & $13: 20$ & + & & 27.2 & 35 & 2 & $\mathrm{~N}$ \\
\hline 36 & 20140527 & Spring & $11: 40$ & $15: 10$ & + & & 24.1 & 44 & 2 & $\mathrm{~S}$ \\
\hline 37 & 20140528 & Spring & $10: 20$ & $13: 40$ & + & & 22.4 & 32 & 2 & SW \\
\hline 38 & 20140529 & Spring & $13: 10$ & $16: 30$ & + & & 25.9 & 30 & 2 & S \\
\hline 39 & 20140530 & Spring & $11: 40$ & 15:00 & + & & 26.6 & 35 & 3 & SW \\
\hline 40 & 20140531 & Spring & $12: 00$ & $15: 20$ & + & & 28.1 & 45 & 3 & $S$ \\
\hline 41 & 20140601 & Summer & $10: 30$ & 13:50 & + & & 28.3 & 44 & 3 & SW \\
\hline 42 & 20140602 & Summer & $10: 30$ & $13: 50$ & + & & 30.0 & 39 & 4 & SW \\
\hline 43 & 20140603 & Summer & $10: 30$ & $13: 50$ & + & & 29.4 & 41 & 4 & SW \\
\hline 44 & 20150418 & Spring & $10: 45$ & 15:05 & + & & 19.3 & 24 & 3 & WSW \\
\hline
\end{tabular}

Table 1. Sample descriptions and associated physical characteristics of the atmosphere. ${ }^{\star}$ Determined by information obtained from the Japan Meteorological Agency, LIDAR, and visibility at the sampling site.

Bacterial community composition was finally represented following calibration by copy number of the $16 \mathrm{~S}$ rRNA gene of each phylum.

Nucleotide sequence accession numbers. The sequences obtained from amplicon sequencing were deposited in the DNA Data Bank of Japan Sequence Read Archive under accession number DRA004472.

\section{References}

1. Perkins, S. Dust, the Thermostat. Sci. News 160, 200-201 (2001).

2. Griffin, D. W. et al. African desert dust in the Caribbean atmosphere: microbiology and public health. Aerobiologia 17, 203-213 (2001).

3. Griffin, D. W. et al. Atmospheric microbiology in the northern Caribbean during African dust events. Aerobiologia 19, 143-157 (2003). 
4. Griffin, D. W. Atmospheric movement of microorganisms in clouds of desert dust and implications for human health. Clin. Microbiol. Rev. 20, 459-477 (2007).

5. Lim, N. et al. Microbiological and meteorological analysis of two Australian dust storms in April 2009. Sci. Total Environ. 412-413, 223-231 (2011)

6. Yoshinaga, S. Accumulation rate of tropospheric dust in and around the Japan islands during the latest quaternary. Quat. Res. 37, 205-210 (1998).

7. Duce, R. A. et al. Long-range atmospheric transport of soil dust from Asia to the tropical North Pacific: temporal variability. Science 209, 1522-1524 (1980).

8. Kellogg, C. A. \& Griffin, D. W. Aerobiology and the global transport of desert dust. Trends Ecol. Evol. 21, 638-644 (2006).

9. Jeon, E. et al. Impact of Asian dust events on airborne bacterial community assessed by molecular analyses. Atmos. Environ. 45, 4313-4321 (2011).

10. Hara, K. \& Daizhou, Z. Bacterial abundance and viability in long-range transported dust. Atmos. Environ. 47, $20-25$ (2012).

11. Maki, T. et al. Phylogenetic analysis of atmospheric halotolerant bacterial communities at high altitude in an Asian dust (KOSA) arrival region, Suzu city. Sci. Total Environ. 408, 4556-4562 (2012).

12. Yamaguchi, N. et al. Global dispersion of bacterial cells on Asian dust. Sci. Rep. 2, 525 (2012).

13. Yamaguchi, N. et al. Changes in the airborne bacterial community in outdoor environments following Asian dust events. Microbes Environ. 29, 82-88 (2014)

14. Maki, T. et al. Variation in the structure of airborne bacterial communities in a downwind area during an Asian dust (Kosa) event. Sci. Total Environ. 488-489, 75-84 (2014).

15. Eoin, L. et al. Urban aerosols harbor diverse and dynamic bacterial populations. Proc. Natl. Acad. Sci. USA 104, 299-304 (2006).

16. Fahlgren, C. et al. Annual variations in the diversity, viability, and origin of airborne bacteria. Appl. Environ. Microbiol. 76, 3015-3025 (2010).

17. Bowers, R. M. et al. Sources of bacteria in outdoor air across cities in the Midwestern United States. Appl. Environ. Microbiol. 77, 6350-6356 (2011).

18. Franzetti, A. et al. Seasonal variability of bacteria in fine and coarse urban air particulate matter. Environ. Biotechnol. 90, 745-753 (2011)

19. Robert, M. B. et al. Seasonal variability in airborne bacterial communities at a high-elevation site. Atmos. Environ. 50, 41-49 (2012).

20. Berry, D. et al. Barcoded primers used in multiplex amplicon pyrosequencing bias amplification. Appl. Environ. Microbiol. 77, 7846-7849 (2011).

21. Ichijo, T. et al. Four-year bacterial monitoring in the international space station-Japanese experiment module "Kibo" with cultureindependent approach. npj Microgravity. 2, 16007 (2016).

22. Quaiser, A. et al. Acidobacteria form a coherent but highly diverse group within the bacterial domain: evidence from environmental genomics. Mol. Microbiol. 50, 563-575 (2003).

23. An, S. et al. Bacterial diversity of surface sand samples from the Gobi and Taklamaken Deserts. Microb. Ecol. 66, 850-860 (2013).

24. Pietikäinen, J. et al. Comparison of temperature effects on soil respiration and bacterial and fungal growth rates. FEMS Microbiol. Ecol. 52, 49-58 (2005).

25. Qian, J. et al. Size-resolved emission rates of airborne bacteria and fungi in an occupied classroom. Indoor Air 22, 339-351 (2012).

26. Nishikawa, M. et al. Source impacts of fall-out dust in Beijing. Proc. Internat. Aerosol Conference Taiwan 433-434 (2002).

27. Tsai, Y. L. \& Olson, B. H. Rapid method for direct extraction of DNA from soil and sediments. Appl. Environ. Microbiol. 57, 1070-1074 (1991).

28. Sutton, N. B. et al. Impact of long-term diesel contamination on soil microbial community structure. Appl. Environ. Microbiol. 79, 619-630 (2013)

29. Sanchez, O. et al. Comparison of different denaturing gradient gel electrophoresis primer sets for the study of marine bacterioplankton communities. Appl. Environ. Microbiol. 73, 5962-5967 (2007)

30. Kawai, M. et al. $16 \mathrm{~S}$ ribosomal DNA-based analysis of bacterial diversity in purified water used in pharmaceutical manufacturing processes by PCR and denaturing gradient gel electrophoresis. Appl. Environ. Microbiol. 68, 699-704 (2002).

31. Caporaso, J. G. et al. QIIME allows analysis of high-throughput community sequencing data. Nat. Methods 7, 335-336 (2010).

\section{Acknowledgements}

This research was supported by the JSPS KAKENHI (Grant-in Aid for Scientific Research [B]) Grant Number 25281030. We thank Toshiaki Hayashi for technical assistance and staff at the School of Allied Health Sciences, Osaka University for support with sampling.

\section{Author Contributions}

N.Y. and J.P. designed the study. J.P. collected bioaerosol samples. J.P. and T.I. analyzed the data. N.Y. and J.P. wrote the manuscript. All authors discussed the results and commented on the manuscript.

\section{Additional Information}

Supplementary information accompanies this paper at http://www.nature.com/srep

Competing financial interests: The authors declare no competing financial interests.

How to cite this article: Park, J. et al. Investigation of bacterial effects of Asian dust events through comparison with seasonal variability in outdoor airborne bacterial community. Sci. Rep. 6, 35706; doi: 10.1038/srep35706 (2016).

This work is licensed under a Creative Commons Attribution 4.0 International License. The images or other third party material in this article are included in the article's Creative Commons license, unless indicated otherwise in the credit line; if the material is not included under the Creative Commons license, users will need to obtain permission from the license holder to reproduce the material. To view a copy of this license, visit http://creativecommons.org/licenses/by/4.0/

(C) The Author(s) 2016 